\title{
Journal of Food Science and Technology Nepal (JFSTN): Past, Present and Future NAWA RAJ DAHAL*
}

\author{
Department of Food Technology and Quality Control (DFTQC), Babarmahal, Kathmandu, Nepal
}

\begin{abstract}
Journal of Food Science and Technology Nepal (JFSTN) is one of the major publications of Nepal Food Scientists and Technologists (NEFOSTA). In the history of its 35 years (from 1984) of formation of NEFOSTA, JFSTN had begun to publish from twenty years (from 2005) and upto the present year of 2019; eleven issues of JFSTN (Volume 1, 2005 to Volume 11, 2019) have already been published and altogether 190 articles of different types (Review articles 39, Research papers 102, Research notes 42,view point 1 and short communication 6) from 16 different countries have been published in these eleven issues of JFSTN. This communication wishes to explore the information about the status, progress and significance as well as way forward for the publication of JFSTN with respect to the development of Food Science and Technology Sector in Nepal.
\end{abstract}

Key words: NEFOSTA, JFSTN, Review article, Research paper, Food Technology, Nepal

\section{Introduction}

Nepal Food Scientists and Technologists Association (NEFOSTA) is solely an autonomous, professional and non-profit making organization of all Nepalese Food Scientists and Technologists formally founded in 1984 in Dharan and later on in 1990 legally registered at CDO office, Kathmandu with Regd, no 224/047-48. It is a professional association of Food Scientists and Technologists with ultimate objective of professional development on Food Science and Technology through innovative ideas and knowledge with continuous advocacy and awareness of this sector. In this regard, NEFOSTA has set the vision of well-developed agro based food industries for better economic prosperity of Nepal as well as increased supply of safe and nutritious food for healthy and active life of Nepalese Citizens.

Publication of Journal of Food Science and Technology Nepal (JFSTN) is one of the major activities of Nepal Food Scientists and Technologists Association (NEFOSTA). In the history of its 35 years from its formation in 1984, JFSTN had begun to publish from twenty years of age (from 2005) and at this moment; eleven issues of JFSTN (Volume 1, 2005 to Volume 11, 2019) have been published. JFSTN is devoted to Research and Development contributions in all branches of Food Science and Technology is an annual publication of NEFOSTA. JFSTN publishes five different types of papers viz(a) Review articles on specific topics of higher utility and current trends (b) Research papers (c) Research notes (d) Viewpoints and (e) Short Communications. From the period of its existence, JFSTN begun to earn its reputation and respect from national and international level. JFSTN is helping many professionals of Food Science and Technology to get their Master's and Ph.D. Degree since publication is must to have Ph.D. Degree and also must to have Master Degree in some of the countries (like China).In addition, publication of paper in JFSTN is also helping professionalsget scholarship abroad to have their academic degrees. There is also an international practice to evaluate the performance of professionals by the number of his/her publication (and the impact factor of the journal where the paper is published) rather than academic degrees only.

\section{Recognition of JFSTN by ISSN and NEPJOL}

In order to recognize the identity of JFSTN at the international level, the process of registration at ISSN (International Standard Serial Number) office situated in France was proceeded in 2005 and JFSTN had been able to register with ISSN 1816-0727 at July 20, 2005 completing the process of evaluation of First issue of JFSTN i.e. Vol 1, 2005.

NEPJOL, Nepal Journal Network, is the network established by Trivuwan University (TU), Kirtipurso as to explore all of the journals published in Nepal in the website $w w w . n e p j o l . i n f o . ~ J F S T N$ had been able to register in NEPJOL at June 8, 2009 and professionals from any corner of the world can access the content of the JFSTN. An agreement was made by TU and NEFOSTA for the inclusion of JFSTN within the NEPJOL. From 2016, JFSTN is being published online including online submission of manuscript and online review process. Nefosta 14th EC (in 2019) uploaded JFSTN Vol 1, Vol 2, Vol 3 and Vol 5 (which were missed to upload) as well on NEPJOL. At present, all issues of JFSTN can be accessed in soft copy via NEPJOL.

\section{Status of paper published in JFSTN}

Journal of Food Science and Technology Nepal (JFSTN) had begun to publish from 2005 and at present (2019), altogether 190 articles of different types (Review articles 39, Research papers 102, Research notes 42, viewpoint 1 and short communications 6) are published in eleven issues of JFSTN; the details is given in Table 1.

On analyzing the status of JFSTN, it is clear that eleven issues are already published and altogether 190 articles are published from 16 different countries, the counties contributing papers are Australia, Bangladesh, Belgium, Burundi, Canada, China, India, Israel, Japan, Nepal, Nigeria, Pakistan, Spain, Srilanka, Thailand and USA (Table 1).

*Corresponding author and Editor- in-Chief, JFSTN, Nepal Food Scientists and Technologist Association (NEFOSTA); email address: nawarajdahal123@gmail.com 
Table 1

Status of Type of Papers published in JFSTN (2005 to 2019)

\begin{tabular}{|c|c|c|c|c|c|c|c|c|c|}
\hline ISSUE & YEAR & $\begin{array}{l}\text { Review } \\
\text { Articles }\end{array}$ & $\begin{array}{c}\text { Research } \\
\text { Papers }\end{array}$ & $\begin{array}{c}\text { Research } \\
\text { Notes }\end{array}$ & $\begin{array}{l}\text { View } \\
\text { Points }\end{array}$ & $\begin{array}{l}\text { Short } \\
\text { Com. }\end{array}$ & $\begin{array}{c}\text { Total } \\
\text { Articles }\end{array}$ & $\begin{array}{l}\text { Total } \\
\text { Pages }\end{array}$ & Countries Contributed \\
\hline JFSTN 1 & 2005 & 6 & 2 & 4 & & & 12 & 72 & Australia, China, Nepal (3) \\
\hline JFSTN 2 & 2006 & 8 & 16 & 3 & & & 27 & 136 & $\begin{array}{c}\text { Australia, China, India, Japan, Nepal, } \\
\text { Nigeria, (6) }\end{array}$ \\
\hline JFSTN 3 & 2007 & 7 & 12 & 1 & & & 20 & 134 & $\begin{array}{c}\text { Australia, China, India, Japan, Nepal, } \\
\text { Nigeria (6) }\end{array}$ \\
\hline JFSTN 4 & 2008 & 3 & 7 & 7 & & & 17 & 79 & $\begin{array}{l}\text { Australia, Bangladesh, China, India, } \\
\text { Japan, Nepal, Srilanka (7) }\end{array}$ \\
\hline JFSTN 5 & 2009 & 4 & 11 & 8 & 1 & 1 & 25 & 164 & $\begin{array}{l}\text { Australia, Belgium, China, India, } \\
\text { Nepal, Srilanka, Thailand (7) }\end{array}$ \\
\hline JFSTN 6 & 2010 & 3 & 12 & 5 & & 1 & 21 & 132 & $\begin{array}{l}\text { Australia, Japan, Thailand, India, } \\
\text { Burundi, Srilanka, Nepal (7) }\end{array}$ \\
\hline JFSTN 7 & 2012 & 3 & 11 & 5 & & 2 & 20 & 120 & $\begin{array}{l}\text { Australia, Belgium, Srilanka, Japan, } \\
\text { Israel, Spain, Canada, India, Thailand, } \\
\text { China, Nepal (11) }\end{array}$ \\
\hline JFSTN 8 & 2013 & 1 & 12 & 2 & & & 16 & 88 & Bangladesh, India, Nepal (3) \\
\hline JFSTN 9 & 2016 & 1 & 5 & 5 & & & 11 & 96 & Thailand, Srilanka, Nigeria, Nepal (4) \\
\hline JFSTN 10 & 2018 & 1 & 8 & & & 1 & 10 & 58 & Australia, Nigeria, Nepal (3) \\
\hline JFSTN 11 & 2019 & 2 & 6 & 2 & & 1 & 11 & 78 & $\begin{array}{l}\text { Australia, Bangladesh, China, Nigeria, } \\
\text { Nepal, Pakistan, Thailand, USA ( } 8 \text { ) }\end{array}$ \\
\hline \multicolumn{2}{|c|}{ Overall } & 39 & 102 & 42 & 1 & 6 & 190 & 1157 & 16 \\
\hline
\end{tabular}

Initially, it was planned to publish JFSTN annually, however JFSTN couldn't be published in the year of 2011, 2014, 2015, and 2017. Target issue, year of publication and responsible editors of JFSTN including tenure of NEFOSTA with Presidents and General Secretaries are given in Table 2.

\section{Workshop on Preparation of Manuscript}

In order to encourage the professional of Food Science and Technology for preparing manuscript from their Research and Development (R\&D) activities (Thesis, Dissertations etc), and to encourage them for publication of those articles in scientific journals targeting Journal of Food Science and Technology, Nepal (JFSTN),
NEFOSTA 14th EC (2018-2020) in collaboration with Department of Food Technology and Quality Control (DFTQC) organized three workshops programs in three major cities (Dhulikhel, Dharan and Pokhara) including 69 participants from 13 different Food Technology colleges all over the country.

First workshop was organized at Dhulikhel (2 days Residential workshop at Hotel Mount Princess), Kavre on 30 and 31 May, 2019 and participants from five different colleges situated in Kathmandu valley participated the workshop, total 22 participants were participated this workshop (Table 3).

Table 2

Target issue and Publication Status of JFSTN

\begin{tabular}{|c|c|c|c|c|c|c|}
\hline $\begin{array}{l}\text { Target } \\
\text { Issue }\end{array}$ & $\begin{array}{l}\text { Published } \\
\text { Issue }\end{array}$ & YEAR & Editor in Chief & Executive Editor & President & General Secretary \\
\hline 1 & JFSTN 1 & 2005 & Ganesh Dawadi & Nawa Raj Dahal & \multirow{3}{*}{$\begin{array}{c}\text { Jagat Bahadur KC } \\
8^{\text {th }} \text { EC }(2004-2006)\end{array}$} & Chandra Prasad \\
\hline 2 & JFSTN 2 & 2006 & Ganesh Dawadi & Nawa Raj Dahal & & Neupane \\
\hline 3 & JFSTN 3 & 2007 & Ganesh Dawadi & Nawa Raj Dahal & & $8^{\text {th }} \mathrm{EC}(2004-2006)$ \\
\hline 4 & JFSTN 4 & 2008 & Ganesh Dawadi & Nawa Raj Dahal & \multirow{2}{*}{$\begin{array}{c}\text { DilipSubba } \\
9^{\text {th }} \text { EC }(2008-2010)\end{array}$} & \multirow{2}{*}{$\begin{array}{l}\text { Megh Raj Bhandari } \\
9^{\text {th }} \text { EC }(2008-2010)\end{array}$} \\
\hline 5 & JFSTN 5 & 2009 & Ganesh Dawadi & Nawa Raj Dahal & & \\
\hline 6 & JFSTN 6 & 2010 & Ganesh Dawadi & Krishna Prasad Rai & \multirow{3}{*}{$\begin{array}{l}\text { Uttam Kumar Bhattarai } \\
10^{\text {th }} \text { EC (2010-2012) }\end{array}$} & \multirow{3}{*}{$\begin{array}{l}\text { Megh Raj Bhandari } \\
10^{\text {th }} \text { EC }(2010-2012)\end{array}$} \\
\hline 7 & & 2011 & Ganesh Dawadi & Krishna Prasad Rai & & \\
\hline 8 & JFSTN 7 & 2012 & Ganesh Dawadi & Krishna Prasad Rai & & \\
\hline 9 & JFSTN 8 & 2013 & Ganga Kharel & & \multirow{2}{*}{$\begin{array}{c}\text { JiwanPrava Lama } \\
\text { 11th EC (2012-2014) }\end{array}$} & \multirow{2}{*}{$\begin{array}{l}\text { Krishna Prasad Rai } \\
\text { 11th EC (2012-2014) }\end{array}$} \\
\hline 10 & & 2014 & Ganga Kharel & & & \\
\hline 11 & & 2015 & Krishna Prasad Rai & & \multirow{2}{*}{$\begin{array}{l}\text { Tirtha Prasad Adhikary } \\
\text { 12th EC (2014-2016) }\end{array}$} & \multirow{2}{*}{$\begin{array}{c}\text { HariharGuragain } \\
\text { 12th EC (2014-2016) }\end{array}$} \\
\hline 12 & JFSTN 9 & 2016 & Krishna PrasadRai & & & \\
\hline 13 & & 2017 & DilipSubba & & JiwanPrava Lama & AtulUpadhyay \\
\hline 14 & JFSTN 10 & 2018 & DilipSubba & & 13th EC (2016-2018) & 13th EC (2016-2018) \\
\hline 15 & JFSTN 11 & 2019 & Nawa Raj Dahal & Santosh Dhakal & $\begin{array}{l}\text { NawarajUpadhyaya } \\
\text { 14th EC (2019-2020) }\end{array}$ & $\begin{array}{l}\text { Rajendra Pd. Adhikary } \\
\text { 14th EC (2019-2020) }\end{array}$ \\
\hline
\end{tabular}


Table 3

First workshop on Manuscript Preparation (30 and 31 May, 2019 at Dhulikhel)

\begin{tabular}{|c|c|c|c|}
\hline $\mathrm{SN}$ & Participants & Colleges & Email \\
\hline 1 & Sumi Regmi & Padmashree international college, Kathmndu & sumiregmi3@gmail.com \\
\hline 2 & Aastha Shrestha & Padmashree international college, Kathmndu & khaastha@gmail.com \\
\hline 3 & Prakriti dhakal & Padmashree international college, Kathmndu & prakritidhakal6@gmail.com \\
\hline 4 & BinitaSubedi & Padmashree international college, Kathmndu & subedibinita2051@gmail.com \\
\hline 5 & PrakritiKhanal & College of Applied Food and Dairy Technology, Ktm & prakritikhanal@gmail.com \\
\hline 6 & SijonKoirala & College of Applied Food and Dairy Technology, Ktm & czankoirala.ck@gmail.com \\
\hline 7 & Raj Kumar Khadka & College of Applied Food and Dairy Technology, Ktm & happyraj2050@gmail.com \\
\hline 8 & SanjayaKarki & College of Applied Food and Dairy Technology, Ktm & karkisanjaya75@gmail.com \\
\hline 9 & AnishaPaudel & College of Applied Food and Dairy Technology, Ktm & poudelanu2055@gmail.com \\
\hline 10 & Priyanka Khanal & Lalitpur Valley College, Lalitpur & khanalpriyanka2@gmail.com \\
\hline 11 & RabinaAwale & Lalitpur Valley College, Lalitpur & rabina817@gmail.com \\
\hline 12 & AbushuyaGuragain & Golden Gate International College, Kathmandu & Anushuyaguragain@gmail.com \\
\hline 13 & Prabesh Acharya & Golden Gate International College, Kathmandu & acharyaprabesh@gmail.com \\
\hline 14 & SubidhyaRupakheti & Golden Gate International College, Kathmandu & Subidhyarupakheti90@gmail.com \\
\hline 15 & Nishma Shrestha & Golden Gate International College, Kathmandu & nishmasth009@gmail.com \\
\hline 16 & NamunaNeupane & Golden Gate International College, Kathmandu & neupanenamuna@gmail.com \\
\hline 17 & Mamata Dhakal & National College of Food Science and Technology, Ktm & mamatadhaka150@gmail.com \\
\hline 18 & Krishikashrestha & National College of Food Science and Technology, Ktm & shresthakrishika@gmail.com \\
\hline 19 & AsminaKunwar & National College of Food Science and Technology, Ktm & asminakunwar12@gmail.com \\
\hline 20 & PrativaUpadhyay & National College of Food Science and Technology, Ktm & uprativa@gmail.com \\
\hline 21 & BijayBhattarai & National College of Food Science and Technology, Ktm & bijaybhattarai21@gmail.com \\
\hline 22 & Pratiksha Shrestha & National College of Food Science and Technology, Ktm & pratikshaa_stha@yahoo.com \\
\hline
\end{tabular}

Similarly, second workshop was organized at Dharan (Gorkha Departmental Store) on 10 and 11 June, 2019 and participants from six different colleges situated at eastern develipment region participated, total 23 participants were participated this workshop (Table 4).

Similarly, third workshop was organized at Pokhara (Hotel Legacy) on 17 and 18 June, 2019 and participants from western development region participated, total 24 participants were participated this workshop (Table 5).
In these three workshops, different topics related to theoretical and practical aspects on manuscript preparation were covered. The classes conducted were on Theoretical Aspects of manuscript Preparation from Dissertations, Preparation of Research Proposal, Experimental Design, Manuscript Preparation, General Framework and Important Considerations, Theoretical and Practical Aspects of Statistical Analysis for Preparation of manuscript, Research Design Techniques, Guidelines for Author and Online Manuscript Submission Technique.

Table 4

Second workshop on Manuscript Preparation (10 and 11 June, 2019 at Dharan)

\begin{tabular}{clll}
\hline SN & \multicolumn{1}{c}{ Participants } & \multicolumn{1}{c}{ Colleges } & \multicolumn{1}{c}{ Email } \\
\hline 1 & SamipSashiPande & Dharan Multiple Campus, Dharan & samipandey108@gmail.com \\
\hline 2 & Alisha Bista & Dharan Multiple Campus, Dharan & Alisabista531@gmail.com \\
\hline 3 & SaritaBimali & Dharan Multiple Campus, Dharan & anarabiama147@gmail.com \\
\hline 4 & SamikshyaRayamajhi & Nilgiri College, Itahari & rusha.niraula2017@gmail.com \\
\hline 5 & Rusha Niraula & Nilgiri College, Itahari & anjanashrestha71@gmail.com \\
\hline 6 & Anjana Shrestha & Central Campus of Technology, Dharan & sthanabindra@gmail.com \\
\hline 7 & Nabindra Shrestha & Central Campus of Technology, Dharan & kshraddha1111@gmail.com \\
\hline 8 & Shraddha Khanal & Central Department of Food Technology, Dharan & senmingrai@gmail.com \\
\hline 9 & SangenRuma Rai & Central Department of Food Technology, Dharan & pdlniraz@gmail.com \\
\hline 10 & NirajPaudel & Central Department of Food Technology, Dharan & subedinesh@gmail.com \\
\hline 11 & Dinesh Subedi & Central Department of Food Technology, Dharan & tankabhattarai55@gmail.com \\
\hline 12 & Tanka Bhattarai & Central Department of Food Technology, Dharan & abinaghale11@gmail.com \\
\hline 13 & AbinaGhale & Central Department of Food Technology, Dharan & Tulasa.Dahal401@gmail.com \\
\hline 14 & TulasaDahal & Central Department of Food Technology, Dharan & agastidhungel75@gmail.com \\
\hline 15 & DimpeshDhungel & Central Department of Food Technology, Dharan & grsharma7@gmail.com \\
\hline 16 & Grishal Sharma & Central Department of Food Technology, Dharan & chalisekrishna69@gmail.com \\
\hline 18 & Krishna Chalise & Central Department of Food Technology, Dharan & chaudharysanzay@gmail.com \\
\hline 19 & Sanjaya Chaudhary & Central Department of Food Technology, Dharan & hemgau@gmail.com \\
\hline 20 & Hemant Gautam & Birat Multiple Campus, Biratnagar & h2.hemanta@gmail.com \\
\hline 21 & Rabin Pyakurel & Sunsari Technical College, Dharan & rabin223344@gmail.com \\
\hline 22 & KeshavTamang & Sunsari Technical College, Dharan & keshavtamang75@gmail.com \\
\hline 23 & Shristy Shrestha & Sunsari Technical College, Dharan & shristii.stha@gmail.com \\
\hline
\end{tabular}


Table 5

Third workshop on Manuscript Preparation (17 and 18 June, 2019 at Pokhara)

\begin{tabular}{clll}
\hline SN & \multicolumn{1}{c}{ Participants } & \multicolumn{1}{c}{ Colleges } & \multicolumn{1}{c}{ Email } \\
\hline 1 & BikashRanabhat & PokharaBigyantathaPrabidhi Campus, Pokhara & bikashofficial10@gmail.com \\
\hline 2 & PratikshyaPokhrel & PokharaBigyantathaPrabidhi Campus, Pokhara & pratikshyapokhrel13@gmail.com \\
\hline 3 & LaxmiAdhikari & PokharaBigyantathaPrabidhi Campus, Pokhara & laxmiadhikari996@gmail.com \\
\hline 4 & Sanjaya Acharya & PokharaBigyantathaPrabidhi Campus, Pokhara & acharyasanjaya920@gmail.com \\
\hline 5 & SarojRanabhat & PokharaBigyantathaPrabidhi Campus, Pokhara & mesarojranabhat@gmail.com \\
\hline 6 & Ramesh Raj Acharya & PokharaBigyantathaPrabidhi Campus, Pokhara & ranges777@gmail.com \\
\hline 7 & Sunil Bhandari & PokharaBigyantathaPrabidhi Campus, Pokhara & sunilbhandari169@gmail.com \\
\hline 8 & Naresh Khanal & PokharaBigyantathaPrabidhi Campus, Pokhara & khanalnaresh1989@gmail.com \\
\hline 10 & SanjayaKhadka & PokharaBigyantathaPrabidhi Campus, Pokhara & paroyaye@gmail.com \\
\hline 11 & Poonam Gupta & PokharaBigyantathaPrabidhi Campus, Pokhara & poonamcfst@gmail.com \\
\hline 12 & Sabina Sunar & PokharaBigyantathaPrabidhi Campus, Pokhara & deewabhandari03@gmail.com \\
\hline 13 & BijayaLamichhane & PokharaBigyantathaPrabidhi Campus, Pokhara & ranusanibas3456@gmail.com \\
\hline 14 & Sujan Mani Dahal & PokharaBigyantathaPrabidhi Campus, Pokhara & bijayalc44@gmail.com \\
\hline 15 & Anita Malla & PokharaBigyantathaPrabidhi Campus, Pokhara & dsujanmani@gmail.com \\
\hline 16 & Jyoti Acharya & NagharaBigyantathaPrabidhi Campus, Pokhara & anitamalla24@gmail.com \\
\hline 17 & Sandesh Lamichhane & Nagarik College, Nawalparasi & ftjyotiacharya@gmail.com \\
\hline 18 & Prabin KC & Nagarik College, Nawalparasi & Sandeshlamichhane10@gmail.com \\
\hline 19 & Biswas Prasad Poudel & Nagarik College, Nawalparasi & prabinkc4626@gmail.com \\
\hline 20 & Shrejana Chaudhary & Nagarik College, Nawalparasi & shankybelief@gmail.com \\
\hline 21 & Shrijana Tiwari & Nagarik College, Nawalparasi & shrijana965@gmail.com \\
\hline 22 & Binita Basnet & Nagarik College, Nawalparasi & srijanatiwari34@gmail.com \\
\hline 23 & LaxmiKandel & Nagarik College, Nawalparasi & basnet.binu@gmail.com \\
\hline 24 & AnjeelaRegmi & Nagarik College, Nawalparasi & laxmikandel28@gmail.com \\
\hline
\end{tabular}

The trainers were Mr. Nawa Raj Dahal (DFTQC), Dr. Alok Shrestha (GoldenGate International College), Dr. Santosh Dhakal (DFTQC), Mr. Santosh Dahal (DFTQC), Mr. Abhisekh Khadka (YPARD, Nepal), Dr. Balkumari Sharma (Ministry of Agriculture and Livestock Development), Mr. Bijan Shrestha (DFTQC) and Mr. Nirat Katuwal (FTQCO, Biratnagar). It was expected that all the participants would be able to prepare manuscripts from their thesis/dissertations and would be able to publish the outcome of their research in scientific journals.

\section{Compilation of JFSTN (Vol 1, 2005 to Vol 10, 2018)}

In order to fulfill the demand of providing all publications of JFSTN, NEFOSTA 14th EC compiled all ten issues of JFSTN and the compiled Book was provided to Food Technology Colleges including NEFOSTA and DFTQC for Library Purposes (Table 6).

NEFOSTA provided this compilation during the Closing Ceremony of Workshop Conducted on Manuscript Preparation (as per Table 3, 4 and 5) to the respective college coordinator. It is expected that students and teachers as well as other R\&D professionals would be benefited from articles published in JFSTN.The compilation contains 179 articles (37 Review Articles, 96 Research Papers, 40 Research Notes, 1 Viewpoint and 6 Short Communications) in the various field of Food Science and Technology from pages from 14 different countries (Australia, Bangladesh, Belgium, Burundi, Canada, China, India, Israel, Japan, Nepal, Nigeria, Spain, Srilanka and Thailand). The compiled book contains total 1079 article pages and all total 1139 pages including preface and content pages.
Table 6

Institutions received Compiled JFSTN

\begin{tabular}{cl}
\hline SN & \multicolumn{1}{c}{ Colleges } \\
\hline 1 & Dharan Multiple Campus, Dharan \\
\hline 2 & Nilgiri College, Itahari \\
\hline 3 & Central Campus of Technology, Dharan \\
\hline 4 & Central Department of Food Technology, Dharan \\
\hline 5 & Birat Multiple Campus, Biratnagar \\
\hline 6 & Sunsari Technical College, Dharan \\
\hline 7 & Padmashree international college, Kathmndu \\
\hline 8 & College of Applied Food and Dairy Technology, Ktm \\
\hline 9 & Lalitpur Valley College, Lalitpur \\
\hline 10 & Golden Gate International College, Kathmandu \\
\hline 11 & National College of Food Science and Technology, Ktm \\
\hline 12 & PokharaBigyantathaPrabidhi Campus, Pokhara \\
\hline 13 & Nagarik College, Nawalparasi \\
\hline 14 & NEFOSTA OFFICE, Babarmahal, Kathmandu \\
\hline 15 & DFTQC, Babarmahal, Kathmandu
\end{tabular}

\section{Way Forward}

It was planned to publish JFSTN on annual basis and first six volumes were also published as planned each year too. However, JFSTN couldn't be published on annual basis from the year of 2011; year 2014, 2015 and 2017 also missed its publication. Based on this experience, it is realized that continuation and sustainability of JFSTN has now demanded the following aspects to be considered by respective professionals and institutions with high priority.

\section{Policy Reformation}

JFSTN now earned its reputation and respect from national and international level. JFSTN is also helping many professionals of Food Science and Technology to get their Master's and Ph.D. Degree since publication is 
mandatory to have Ph.D. Degree and also must to have Master Degree in some of the countries (like China). In addition, publication of paper in JFSTN is also helping professionals to get scholarship abroad for further studies. There is also an international practice to evaluate the performance of professionals by the number of his/her publication (and the impact factor of the journal where the paper is published) rather than academic degrees only. Based on this fact, Academic Institutions may formulate the policy of getting at least one publication by the student based on his/her research carried out to pursue Master's Degree (if possible at least a research note or brief review paper for Four Years Bachelors Degree too) mandatorily. This type of regulations is already established in some countries like China for Master Degree. Similarly Academic Institutions as well as Government Research and Development Institutions may also establish the regulation of performance evaluation of academic professionals based on their publication status either for promotion or for other means. These two policy reformations which are also academic and scientific approaches if followed by respective institutions, will also indirectly support for the publication of JFSTN on annual basis.

\section{Publication Leadership from Academic Sector}

On analysing the publication history of JFSTN, it is recorded that editorial leadership (Editor in chief, Executive Editor and other editors) is being provided from the professionals working out of direct academic institutions. Since publication of JFSTN is highly relevent to academic task, continuation of publication of JFSTN would be more sustainable and more relevant if its leadership would be taken by the professionals directly involved in Academic Institutions.

\section{Submission of manuscript to JFSTN}

Professionals related to Food Science and Technology are requested to submit their original manuscript (both online submission in Nepjol and email Submission to Editorial board) of review articles, research papers, viewpoints and short communications.

- Online submission: In case of online submission, please follow authors guidelines for submission of online manuscript submission which is uploaded on Nefosta website: nefosta.org.np

- Email Submission: In case of email submission, please email to jfstn@,nefosta.org.np. Contributors are requested to follow Guidelines for Authors critically while preparing their manuscripts. Guideline for Author is available in NEFOSTA website: nefosta.org.np

Any further clarification or confusion regarding the preparation of manuscript and publication can also be addressed to editorial board of JFSTN.

\section{Contact address for subscription of JFSTN and for other details}

For subscription of JFSTN and other particulars, contact address is as follows.
The General Secretary, Nepal Food Scientists and Technologists Association (NEFOSTA) C/O Department of Food Technology and Quality Control, Kathmandu, Nepal. Phone: 00977-1-4256624,00977-1-4262369; Fax: 00977-1-4-262337,Email: info@nefosta.org.np.

\section{Concluding remarks}

In the history of 35 years of establishment of NEFOSTA, the activity of publication of JFSTN started from 2005 and at the end of thirty five years, eleven issues of JFSTN have been published. At this moment (2019), altogether 190 articles of different types (Review articles 39, Research papers 102, Research notes 42, view point 1 and short communication 6) as contributed by professionals from 16 different countries are published in these eleven issues of JFSTN. In this period, JFSTN has earned good reputation and scientific forum as well as received good appreciation from the respective professionals and related institutions. Of course, publication of journal is a challenging task but it has opened the tremendous opportunities to professionals and institutions to exchange and disseminate the developed knowledge on Food Science and Technology both at the national and international level. Continuity of the publication of JFSTN is great success of NEFOSTA to achieve its objective. It is expected to continue publishing as well as improving the quality of this journal regularly and concerned professionals are kindly requested for providing valuable feedbacks and suggestions with support for continuity and sustainability of JFSTN.

\section{References}

Agreement made between NEPJOL and NEFOSTA at June 8, 2009

NEFOSTA (2005). Journal of Food Science and Technology Nepal, Volume 1, 2005

NEFOSTA (2006). Journal of Food Science and Technology Nepal, Volume 2, 2006

NEFOSTA (2007). Journal of Food Science and Technology Nepal, Volume 3, 2007

NEFOSTA (2008). Journal of Food Science and Technology Nepal, Volume 4, 2008

NEFOSTA (2009). Journal of Food Science and Technology Nepal, Volume 5, 2009

NEFOSTA (2010). Journal of Food Science and Technology Nepal, Volume 6, 2010

NEFOSTA (2012). Journal of Food Science and Technology Nepal, Volume 7, 2012

NEFOSTA (2013). Journal of Food Science and Technology Nepal, Volume 8, 2013

NEFOSTA (2016). Journal of Food Science and Technology Nepal, Volume 9, 2016

NEFOSTA (2018). Journal of Food Science and Technology Nepal, Volume 10, 2018

NEFOSTA (2019). Journal of Food Science and Technology Nepal, Volume 11, 2019

Recognition Letter received by ISSN office France at July 20, 2005 